\title{
OF FENCES AND PEACE BETWEEN NEIGHBOURS
}

\section{Introduction}

The speaker in the poem "Mending Wall" by American poet Robert Frost questions the wisdom of the saying that "Good Fences Make Good Neighbo[u]rs" (1914 North of Boston lines 27 and 45). The walls or fences referred to in the poem represent more than just physical barriers separating adjacent premises; the speaker sees them as representing obstacles to communication and friendship between individuals. Seen from the perspective of the speaker, a fence or wall is a "bad" thing. But the speaker is but one of the parties to the neighbourly relationship. For the speaker's neighbour, a wall or a fence is "a protector of privacy" (Watson "Frost's Wall: The View from the Other Side" 197144 The New England Quarterly 653 655). Thus there are two views on walls or fences: they can be seen negatively as obstructing good relations, or positively as dividers that secure good relations between neighbours by separating them and protecting their privacy rights.

What do dividers (or barriers), physical or otherwise, have to do with law? During recent research visits to the Durban Magistrate's Court (October 2007, February 2008) the author noted with interest that magistrates at the Durban court often had to deal with applications for binding-over orders (or "peace orders") intended to secure the peace between neighbours. Bindingover orders can be seen as legal "fences" or "walls" established in terms of statute at the request of one of the parties where violence or threats of violence imperil the peaceful co-existence of neighbours.

Section 384 of the Criminal Procedure Act 56 of 1955 - which allows for such applications - is one of only two sections of that Act that remains on the statute book. The provisions of section 384 have been called archaic and irrelevant in view of the provisions of the Domestic Violence Act of 1998 and its 1993 predecessor (Kriegler and Kruger Hiemstra Suid-Afrikaanse Strafproses 6ed (2002) 939). Seen in this light, a reconsideration of section 384 seems redundant. But the matter is not that simple. The application of the Domestic Violence Act requires the existence of a domestic relationship between the parties as defined in section 1 of that Act. The complainant who approaches a magistrate for a binding-over order in terms of section 384 and the person against whom the order is sought may not be in a domestic relationship as defined in the Act, thus ruling out the application of the Domestic Violence Act. Therefore, section 384 goes wider in that it aims to preserve the peace within a broader context than the Domestic Violence Act. Consequently reconsideration thereof is warranted. 
In this note the author discusses the provision for binding-over orders as set out in section 384 of the Criminal Procedure Act of 1955. In order to do so, she traces the origins thereof before considering the specific scope of section 384. In the main she analyses the constitutionality of this section in the light of relevant jurisprudence of the Constitutional Court and comparative jurisprudence of the European Court of Human Rights. She concludes with a recommendation.

\section{The origin of binding-over orders in South African law}

The South African legislative provision for binding-over orders (or peace orders) has its origins in English law ( $R v$ Limbada 19532 SA 368 (N) 370). In its report on binding-over orders published in 1994, the Law Commission of the United Kingdom noted that the "origins of the powers to bind over are lost in history" (The Law Commission Binding Over: Report on a Reference under Section 3(1)(e) of the Law Commissions Act 1965 (1994) 7 (hereinafter "Binding Over"). The details of its origins may have been lost, but some information remains. The powers to bind a person over to hold the peace have been traced as far back as the tenth century (Binding Over 7-8). It has been recorded that knights in the twelfth century were responsible for the enforcement of oaths of the peace. This responsibility led to the creation of the office of the conservator of the peace. This office was transformed into that of the justice of peace in the fourteenth century. At first, justices of the peace had the power to hear and decide criminal matters. The Justices of the Peace Act 1361 consolidated the role and position of these officials in exercising social control, which included the power to bind a person over to be of "good behaviour towards the King and his people". This fourteenth century statute is still in force in the United Kingdom (Binding Over 7, 89) and a statutory complaint procedure to deal with binding-over orders is provided for in the United Kingdom's Magistrates' Courts Act of 1980.

The first mention of the power to bind a person over to keep the peace in South Africa can be found in the "Ordinance for creating Justices of the Peace in this Colony" [Ordinance 32 - 11 December 1827] which established the office of justices of the peace for the Cape Colony. Section 2 of this Ordinance required justices of the peace to preserve public peace and granted these officials jurisdiction in criminal matters. In addition thereto section 2 stipulated that

\footnotetext{
"the said Justices of the Peace are hereby authorised and required, upon information or complaint in writing upon oath made to them, or any of them, to cause to come before them all those who have used any threats towards any person or person, whether regarding their bodies or the firing of their houses, and to require of them sufficient security for the peace, or their good behaviour towards His Majesty or his subjects; and if they shall not give such security then to cause them to be safely kept in prison till they shall find such security".
}

A binding-over order granted under this section did not depend on the commission of a criminal offence or a conviction of a criminal offence. Mere 
disturbance of the peace by a person could justify the granting of such an order. The provisions of Ordinance 32 of 1827 were extended to the district of Natal through the enactment of the Justices of the Peace Ordinance 6 of 1846. A similar provision was enacted in the Orange River Colony after the Anglo-Boer War in 1902 with the enactment of Ordinance 6 of 1902 to provide for the appointment of justices of the peace in that colony. The Criminal Procedure Code Ordinance 1 of 1903 provided differently for the Transvaal Colony. Section 261 thereof provided for binding over of a person convicted of a criminal offence in addition or instead of other punishment. Binding-over proceedings in the Transvaal Colony thus fulfilled a different role and could only follow a criminal conviction.

The provisions in relation to binding over as applicable in the different colonies were repealed by the Criminal Procedure and Evidence Act 31 of 1917 which consolidated and amended the rules in relation to criminal procedure and evidence for the Union of South Africa. Section 387 of the 1917 Act contained wording very similar to that found in section 384 of the 1956 Act which repealed the 1917 Act.

\section{The scope and nature of proceedings in terms of section 384}

In terms of section 384(1) a person may make a complaint on oath to a magistrate setting out that another is conducting herself or himself violently, or is threatening injury to the person or property of another, or that she or he used language or behaved in a manner towards another that is likely to provoke a breach of the peace or an assault, in public or in private. Upon receipt of this complaint, the magistrate may order the person named in the complaint to appear before her or him. If necessary, the magistrate may order for the person to be arrested and brought before her or him. The magistrate must then "enquire into and determine upon the complaint". Evidence on oath regarding the complaint may be considered by the magistrate. Having heard the evidence the magistrate has a discretion to order the person against whom the complaint was made to give recognisances (with or without sureties) of not more than R2 000 for a period not longer than six months to keep the peace towards the complainant and to refrain from doing or threatening injury to the person or property of the complainant. Refusal or failure to give the recognisances as ordered may result in the committal to gaol of the person against whom the order was made by an order of the magistrate for a period not exceeding six months ( $\mathrm{s}$ 384(3)). Costs incidental to the inquiry may be ordered against the person bound over to keep the peace (s 384(2)). A breach of the conditions of the order may result in a forfeiture of the recognisances by an order of the magistrate. The forfeiture order has the effect of a judgment in a civil action in the Magistrate's Court (s 384(4)).

There are only two reported judgments dealing with this section or the similarly worded section in the 1917 Criminal Procedure Act. These are $R v$ Limbada (1953 2 SA $368(\mathrm{~N})$ ) and Williamson v Helleux NO (1978 2 SA 348 
$(T))$. Both these judgments were delivered prior to the advent of constitutional democracy in South Africa. These judgments make it clear that the provision for binding over is based in statute and that the powers of the magistrate are limited to those set out in the specific section $(R v$ Limbada supra 370C-D; Williamson v Helleux NO supra 351C-E). In Williamson v Helleux NO Coetzee $\mathrm{J}$ acknowledged the English law roots of the provision but maintained that the powers of the magistrate were limited to those set out in the statute. In both judgments it was held that binding-over orders are of a preventative nature and it was stated unequivocally that the person ordered to be bound over is not convicted of an offence ( $R v$ Limbada supra 370C; Williamson v Helleux NO supra 351G, and see also Hiemstra SuidAfrikaanse Strafproses (1967) 505). This does not mean that the conduct that led to the binding-over order does not amount to an offence. The court held that it may well do ( $R v$ Limbada supra 370B). Failure to give the recognisances as ordered may lead to imprisonment of the person against whom the order was made, thus curtailing her or his freedom. Coetzee $\mathrm{J}$ in Williamson held that the proceedings in terms of this section are administrative and of a quasi-judicial nature $(352 \mathrm{G}-\mathrm{H}$; $353 \mathrm{H}$, and see also Roets "Toepassing van A 384 van die Strafproseswet 56 van 1955" 1990 25(2) The Magistrate 75-77). In the view of the judge, the magistrate binding a person over is not fulfilling a judicial task and nor is her or his order an order of court. This finding has major repercussions. It means that neither the person applying for a binding-over order nor the person against whom the order is sought is entitled to legal representation (Williamson $v$ Helleux NO supra 353A). The requirement that the proceedings are to be conducted fairly and in accordance with the principles of natural justice remains (Williamson $v$ Helleux NO supra $352 \mathrm{H}-353 \mathrm{~A}$ ). The inquiry may be quite informal without formal evidence being led (Williamson $v$ Helleux NO supra $352 \mathrm{H}$ ). Evidence may be taken on oath from persons present, but witnesses may not be compelled to testify in these proceedings (Williamson $v$ Helleux NO supra 353B). The court's ruling on the nature of the proceedings as administrative or quasi-judicial also means that an order in terms of this section is not appealable ( $R v$ Limbada supra 370A). It also means that the grounds for review of such orders are restricted since the order made is not that of an "inferior court" as required by section 19(1) of the Supreme Court Act of 1959 (Williamson v Helleux NO supra 353F-G). The powers of review in respect of such orders are limited to those that exist under common law, for example mala fides on the part of the magistrate who refuses to exercise her or his discretion to grant the order to bind a person over to keep the peace (Williamson v Helleux NO supra $353 \mathrm{H}$ ).

In Williamson the judge noted that the discretion of the magistrate to grant the binding-over order is limited. The magistrate may only order the person to give recognisances on condition that he or she keeps the peace towards the complainant and refrains from injuring or threatening the person or property of the complainant (Williamson $v$ Helleux NO supra 353C-F). This means that the statute does not provide for specific conduct to be prohibited (Williamson v Helleux NO supra 353F). The nature of the conduct that could, in the discretion of the magistrate, justify the granting of such an order, must, 
according to Coetzee $\mathrm{J}$ in Williamson involve "personal physical violence and injury" directed at a person or his or her property that could lead to a breach of peace (Williamson v Helleux NO supra 354C and 354F-G).

\section{Constitutional and human rights standards}

Given the exposition of the provisions of section 384 and the interpretation thereof by the erstwhile Supreme Court, the question arises as to whether this section passes constitutional muster. Binding-over proceedings could result in the detention of a person who was bound over to keep the peace should that person refuse or be unable to give the recognisances as ordered by the magistrate. Such a detention will clearly limit the right to freedom and security of the person as provided for in section 12 of the Constitution of the Republic of South Africa, 1996. It also affects the parties' right of access to court in so far as the right of appeal is concerned (s 34 of the Constitution). It therefore has to be determined whether section 384 limits these rights and whether these limitations are justifiable.

The concept of binding over has not been addressed explicitly by the Constitutional Court. However, the court's interpretation of other statutory provisions which could also result in the deprivation of freedom may shed some light on the constitutionality of this concept. These include the judgments of the court in Coetzee $v$ Government of the Republic of South Africa; Matiso v Commanding Officer, Port Elizabeth Prison (1995 10 BCLR 1382 (CC)); Ferreira v Levin NO (1996 1 BCLR 1 (CC)); Bernstein v Bester NO (1996 4 BCLR 449 (CC)); Nel $v$ Le Roux NO (1996 4 BCLR 592 (CC)); S $v$ Coetzee (1997 4 BCLR 437 (CC)); De Lange v Smuts NO (1998 7 BCLR 779 (CC)); S v Baloyi (Minister of Justice Intervening) (2000 1 BCLR 86 (CC)); and Omar v Government, RSA (2006 2 BCLR 253 (CC)).

The person who is bound over is not subjected to criminal prosecution and is thus not an accused person entitled to the rights set out in section 35 of the Constitution (see Ferreira $v$ Levin NO supra par 41 and par 3 above). This does not leave the person bound over without constitutional protection. It is most notably the right to freedom of the person bound over that is at stake as explained above. This right has been interpreted to encompass two aspects, namely a procedural and a substantive aspect $(S v$ Coetzee supra par 159; Bernstein v Bester NO supra par 145-146; and De Lange v Smuts NO supra par 17-23). The deprivation of freedom will only meet constitutional standards if it comes about after following a due process and only if the deprivation of freedom is for a constitutionally acceptable purpose (see De Waal "Revitalising the Freedom Right? De Lange $v$ Smuts NO 1998 3 SA 785 (CC)" 1999 SAJHR 217 219). In what follows, the author considers both these aspects in relation to binding-over proceedings.

\section{Substantive aspects}

The substantive aspect of the freedom right requires the deprivation of freedom to take place for a cause that is just. This requires the reason for 
the deprivation of freedom to be constitutionally permissible. It also requires that a rational connection exists between the deprivation of freedom and the objectively determinable purpose served by the deprivation (De Lange $v$ Smuts NO supra par 23). In De Lange, Ackermann J noted that it would be impossible to define what would constitute a "just cause" for the deprivation of freedom in all imaginable circumstances. He therefore proposed that the law in this regard be developed incrementally and on a case-by-case basis. The judge added 'the concept of 'just cause' must be grounded upon and consonant with the values expressed in section 1 of the 1996 Constitution and gathered from the provisions of the Constitution as a whole" (par 30).

What is the purpose of binding-over proceedings? Is that purpose constitutionally permissible, that is, rooted in the values set out in section 1 of the Constitution? Following section 384 proceedings, the detention of a person is a real possibility, even though it is not the purpose of these proceedings. A person will only be bound over to keep the peace where his/her actions have breached the peace or are likely to provoke a breach of the peace. When do the actions of a person amount to a breach of the peace? More pertinently, is the concept "breach of the peace" sufficiently clear to guide the behaviour of citizens? Section 39(2) of the Constitution allows a court to consider foreign law in the interpretation of the rights entrenched in the Bill of Rights. When it comes to the right to freedom and the meaning of "breach of the peace" some insight is to be gained from the judgment of the European Court of Human Rights (ECHR) in the matter of Steel $v$ The United Kingdom ((67/1997/851/1058) 23 September 1998 http://hei.unige.ch/ clapham/hrdoc/docs/echrsteel.pdf accessed 2008-04-25) and the UK Law Commission Report on binding over referred to above. The consideration of the judgment and the report must take place against the background of English Law on binding-over which is different to our section 384 procedure.

In terms of English law binding-over orders may be made in terms of the Magistrates' Courts Act of 1980, the common law and the Justices of Peace Act of 1361 (Binding Over 8-9). Ms Steel and her co-applicants were activists protesting organised hunting (first applicant, Steel $v$ The United Kingdom supra par 6-13), the construction of a highway (second applicant, Steel $v$ The United Kingdom supra par 14-19), and the sale of fighter helicopters (third, fourth and fifth applicants, Steel $v$ The United Kingdom supra par 20-24). All the applicants were on separate occasions arrested for a breach of the peace. For purposes of this discussion the matters of the first and second applicants are of interest and the author restricts her discussion to these matters.

At their first court appearances the first and second applicants were found to have breached the peace. They were ordered to agree to be bound over for a specified number of months against specified recognisances (Steel $v$ The United Kingdom supra par 13 and 19). Both applicants refused to be bound over and were committed to prison for a specified number of days (Steel $v$ The United Kingdom supra par 13 and 19). The applicants challenged the provision for binding over orders set out in section 115 of the 
Magistrates' Court Act, 1980 as infringing their rights under articles 5, 6 and 13 of the European Convention on Human Rights (Steel $v$ The United Kingdom supra par 41). The applicants raised a number of arguments. For purposes of this discussion, their argument that "the concept of breach of the peace and the power to bind over were not sufficiently clearly defined for their detention to be "prescribed by law'" as required by art 5(1) of the Convention (Steel $v$ The United Kingdom supra par 39) is important.

In considering the human rights implications of the challenged concept, the European Court considered the definition of breach of peace and the powers of binding over in terms of English law (Steel $v$ The United Kingdom supra par 25-38). The court noted specifically that the Court of Appeal formulated a definition of the concept in $R v$ Howell [1982] Queen's Bench Reports 416427 (Steel $v$ The United Kingdom supra par 25):

"there is likely to be a breach of the peace whenever harm is actually done or is likely to be done to a person or in his presence to his property or a person is in fear of being so harmed through an assault, an affray, a riot, unlawful assembly or other disturbance".

The ECHR supplemented this definition of the concept considering the 1995 judgment of a Divisional Court (Percy v Director of Public Prosecutions [1995] 1 Weekly Law Reports 1382) which required some risk of violence for a breach of the peace to occur (Steel $v$ The United Kingdom supra par 27). These definitions satisfied the judges of the European Court regarding the clarity of the concept of "a breach of the peace" and they held that "the relevant legal rules provided sufficient guidance and were formulated with the degree of precision required by the Convention" (Steel $v$ The United Kingdom supra par 55). The detention of the first and second applicants following their refusal to be bound over was not found to be arbitrary since it followed a finding that the parties had breached the peace (Steel $v$ The United Kingdom supra par 75). The detention followed an order made by a court of law in terms of law which meets the standards set by the Convention. As such the order was held to be unassailable.

The finding of the ECHR in Steel can be contrasted with the view of the Law Commission of England (referred to above) which recommended in 1994 that the binding-over orders be abolished. The Commission was of the view that the concept "breach of peace" was vague and imprecise (Binding Over 32-40) and thus contrary to the rule of law and the human rights standards applicable to English Law (Binding Over 59-62). The Commission was also of the view that there were adequate other legal provisions to deal with behaviour that ordinarily attracted binding-over orders (Binding Over 2526). Despite this recommendation, no steps have been taken in the United Kingdom to abolish binding-over proceedings. The judgment in Steel strongly counters the view of the Law Commission and the author bases her assessment of the substantive aspect relating to the freedom right on the ECHR judgment rather than on the report of the Law Commission. In its judgment the ECHR noted that the Law Commission recommended abolition of the power to bind over, but it still found that the concept was adequately defined and rationally related to a purpose commensurate with the human 
rights standard set by the European Convention on Human Rights (see Steel $v$ The United Kingdom supra par 54-55).

It stands to reason that the maintenance of peace in society is constitutionally worthwhile. A society in which people resort to violence or threaten to resort to violence would be anarchic. The Steel judgment provides persuasive authority for the view that the concept of "a breach of the peace" is sufficiently precise to constitute a "just cause" that is constitutionally permissible. It also provides authority for the view that binding-over proceedings are rationally related to the worthwhile purpose of preventing a breach of the peace. Once it is found that a person has breached the peace and that person is bound over to keep the peace, a failure to give the recognisances as ordered justifies detention.

\section{Procedural aspects}

As stated above, the freedom right encompasses both substantive and procedural aspects ( $S$ v Coetzee supra par 159; Bernstein v Bester NO supra par 145-146; De Lange $v$ Smuts NO supra par 17-23). These aspects are inextricably linked and it is important to consider the procedural aspect of the right to freedom in the light of the nature and the purpose of the deprivation of freedom (De Waal 1999 SAJHR 225-226). The procedural aspect of the freedom right requires fairness of the "trial" leading to the deprivation of freedom (De Lange $v$ Smuts NO supra par 42). Do bindingover proceedings qualify as a fair trial? In this regard it should be borne in mind that the erstwhile Supreme Court deemed binding-over proceedings to be quasi-judicial or administrative in nature (see the discussion at par 3 above), a finding with serious implications. This finding regarding the nature of binding-over proceedings implies that an appeal against a binding-over order is not possible, that review options are limited and that legal representation is not allowed. Does this appraisal of the nature of bindingover proceedings still hold? A consideration of the Nel and De Lange judgments of the Constitutional Court and the provisions under scrutiny in those cases may shed some light on the matter.

At stake in Nel $v$ Le Roux (supra) was the constitutionality of section 205 of the Criminal Procedure Act 51 of 1977. This section is an evidencegathering mechanism that allows the questioning of a person believed to have essential information regarding an alleged offence, by the Director of Public Prosecutions before a judicial officer. In relation to the nature of these proceedings, Ackermann J, for the court, stated (par 15):

"As far as section 205 of the CPA is concerned the entity [presiding over the hearing] is indeed a normal judicial officer who ordinarily functions in the ordinary courts. The 'court' before which the section 205 enquiry takes place is in every material respect, particularly insofar as its independence and impartiality is concerned, identical to the "ordinary court of law' envisaged by section 25(3) of the [interim] Constitution."

Section 189(4) of the Criminal Procedure Act which is to be read with $s$ 205 makes it clear that an order in terms of this section is subject to appeal 
in the same manner as a sentence imposed in any criminal case ( $\mathrm{Nel} v \mathrm{Le}$ Roux NO supra par 24). Section 205 of the CPA does not explicitly allow for legal representation of the person questioned in terms of that provision. Over the years our courts have interpreted that fairness and rules of natural justice require that such an examinee be allowed to obtain legal representation (Du Toit et al Commentary on the Criminal Procedure Act Service 33 (2004) 23-53).

The constitutionality of a provision of the Insolvency Act 24 of 1936 which allows the committal of a recalcitrant witness to gaol was considered in $D e$ Lange $v$ Smuts (supra). In the court a quo, Conradie $\mathrm{J}$ held that the proceedings presided over by a magistrate in terms of the Insolvency Act were administrative in nature and not judicial (De Lange $v$ Smuts NO 1997 11 BCLR 1553 (C) 1557C-E). In the Constitutional Court, Ackermann J did not make any finding as to the nature of the function of the magistrate in presiding over a meeting of the creditors. However, his finding in respect of the nature of issuing a committal warrant for a recalcitrant witness at such a meeting is insightful (par 79-80). The judge held:

"This [the issuing of a committal warrant] is in substance a judicial proceeding even if it not conducted in a court of law. I have no doubt in my mind that the process of factual and legal evaluation involved in deciding whether or not to commit an examinee to prison and the act of issuing the committal warrant, are clearly judicial and nothing else."

The person detained in terms of the provisions of the Insolvency Act may apply to court for discharge from custody which the court may order in the event where the person was wrongfully committed to prison or detained wrongfully (s 66(5)). A witness interrogated at a meeting of the creditors in terms of the Insolvency Act has the right to be assisted by counsel, an attorney or an agent (s 65(6) and see Bertelsmann et al Mars: The Law of Insolvency in South Africa 9ed (2008) 423).

The proceedings in terms of the CPA (in Nel) and Insolvency Act (in Smuts) were held to meet the constitutional standards for a "fair trial". The similarity between the proceedings in terms of these statutes and bindingover proceedings leads the author to the conclusion that binding-over proceedings are judicial in nature rather than administrative or quasi-judicial as was held by the erstwhile Supreme Court. A magistrate presiding over proceedings in terms of section 384 has to engage in a process of "legal and factual evaluation" not much different from the proceedings at stake in $\mathrm{Nel}$ and Smuts. But such a re-appraisal does not necessarily address all the fairness concerns in respect of binding-over proceedings. The Criminal Procedure Act and the Insolvency Act explicitly allow for reconsideration of the detention order made thereunder by means of an appeal (in the instance of the CPA) or on application (in the instance of the Insolvency Act). Bindingover orders made in terms of English law are subject to appeal (Magistrates' Courts (Appeal from Binding-Over Orders) Act 1956). It would thus seem as if an explicit legislative allowance for reconsideration of detention orders is required. In the absence of an express provision allowing for a reconsideration of the merits of a person's detention as a result of binding- 
over proceedings, it thus has to be accepted that there is none in the present form of binding-over proceeding in South African law. This, in the author's view, is problematic. Examinees in terms of the Insolvency and Criminal Procedure Acts are entitled to legal representation/counsel. In the instance of the Insolvency Act this provision is explicit. From the discussion above relating to legal representation in section 205 (CPA) proceedings, it is evident that our courts acknowledge the benefit of legal counsel in the pursuit of justice, as well as its importance in securing a fair hearing. Section 384 of the Criminal Procedure Act of 1956 should be considered in a similar light. A party to binding-over proceedings should be allowed legal representation in the interest of fairness and justice.

\section{$5 \quad$ Conclusion and recommendation}

Does section 384 pass constitutional muster? The maintenance of peace in society is a purpose worthy of pursuit by fair means. Section 384 provides for an uncomplicated way of dispute resolution aimed at securing the peace. In terms of this section a magistrate receives a complaint regarding a disturbance of the peace, hears evidence upon oath on this and exercises his or her discretion to bind a person over to keep the peace; in short, the magistrate erects a legal fence between bickering neighbours in an attempt to preserve the peace. This simplified version of binding-over proceedings in terms of section 384 makes the section seem unproblematic. From the discussion above it is clear that the situation is not that simple. At the moment precedent informs our interpretation and understanding of this concept in a way that is constitutionally questionable. The absence of an explicit legislative provision to allow for reconsideration of binding-over proceedings is even more problematic. Legislative intervention is thus required to amend this section. Clarification regarding the nature of the proceedings and an explicit provision to allow for the reconsideration of a detention order granted in terms of this section are necessary.

While the speaker in Frost's poem may think that "[s]omething there is that doesn't love a wall" ("Mending Wall" line 1), the "wall" that can be erected in terms section 384 , subject to the author's recommendations, may indeed continue to preserve good neighbourly relations in Durban and elsewhere. 